\title{
Paulus Oecumenicus: Interculturality in the Shaping of Paul's Theology*
}

\author{
ANDRIE DU TOIT \\ New Testament Research Unit, University of Pretoria, P O Box 92345, Mooikloof, \\ o059 Pretoria, South Africa \\ email: andriedt@icon.co.za
}

The growing recognition that Judaism and Hellenism were not mutually exclusive suggests that Paul should be studied from a point beyond the Judaism/ Hellenism divide. After attending to the apostle's own multiculturality, the relevance and implications of the 'beyond' position are assessed by means of an enquiry into Paul's use of charis and ecclesia. In both instances, intercultural convergence is indicated. However, the farewell to a dichotomous point of departure does not imply the denial of all distinctiveness. Studying the biblical documents from the 'beyond' position opens up new vistas and holds great promise for future NT research.

Keywords: Paul, interculturality, presuppositions, grace, church

\section{Preliminary Observations}

\subsection{Bridging the Judaism/Hellenism Divide}

The traditional notion of an unbridgeable dichotomy between Judaism and Hellenism has a direct bearing on Pauline studies.

Paul the apostle was born and bred a Jew of the diaspora, nurtured in the traditions of his Jewish forebears, yet at the same time imbibing an all-pervading Hellenistic culture - hence a Hellenistic Jew in the full sense of the word, not merely a Jew who happened to preach and write in Greek. However, being simultaneously Hellenistic and Jewish encapsulates one of the most controversial issues in Pauline studies. What relative weight should we allocate to each of these epithets? Should the writer of at least seven of our oldest extant Christian documents be understood from a primarily Hellenistic perspective or a Jewish one? Or is this a false dichotomy?

* Presidential address delivered to the 63rd Annual Meeting of the Studiorum Novi Testamenti Societas at the University of Lund, July 29-August 22008. 
The presumption that Jewishness and Hellenism were two incompatible, in fact, strongly oppositional entities, ${ }^{1}$ forced the quest for the authentic Paul into an either/or paradigm. First Ferdinand Christian Baur, followed by the history of religions school, created a thoroughly Hellenized Paul. A counter reaction was inevitable. The cumulative effect of the work of such divergent spirits as Paul Billerbeck, Joachim Jeremias, W. D. Davies, E. P. Sanders and many others largely succeeded in restoring a Jewish Paul.

The last few decades saw the pendulum moving backwards once more. Indications of affinity between Paul's oeuvre and Hellenistic culture are accumulating, thereby unmasking the one-sidedness of an exclusively Jewish approach. Following on the discovery that both Judaism and Hellenism were not monolithic entities, it is increasingly being recognized that Jewishness and Hellenism are, in many respects, not mutually exclusive. The either/or dichotomy is being unmasked as an ideologically based presupposition. In the wording of Engberg-Pedersen, we should now approach Paul from a point 'beyond the Judaism/Hellenism divide'.

Does this farewell to a dichotomous approach then imply the denial of all distinctiveness? We know that even in multi-cultural societies distinctive identities and religious diversity can stubbornly hold their ground. ${ }^{3}$ The 'beyond' should therefore rather be understood as a vantage point - one which is not distorted by a massive either/or disposition, but which allows for communalities and convergences, but also for hard-core incompatibilities. These factors should be kept in mind when we turn to the manner in which Paul communicated the Christian message within shifting contexts. We start with two aspects of his own life setting.

\subsection{Situating Paul}

\subsubsection{Paul's own Multiculturalism}

In his well-known work Tarsus or Jerusalem, van Unnik stated quite categorically that these two cities represented two radically different worlds. ${ }^{4}$ The choice between Tarsus and Jerusalem was therefore one between two different Pauls: a universalistic, Hellenistic one, and a conservative, Jewish one. He set out to prove that Paul grew up in Jerusalem and that he was, in fact, a thoroughbred Palestinian Jew. However van Unnik's position can no longer be maintained. On the one hand, we know today that the first century Jerusalem was

1 The prominent scholar H. D. Betz ('Hellenism', ABD III 129) called emerging Christianity 'the intellectual and spiritual battleground on which the confrontation between Judaism and Hellenism was fought with unprecedented intensity'.

2 T. Engberg-Pedersen, 'Introduction', Paul beyond the Judaism/Hellenism Divide (ed. T. Engberg-Pedersen; Louisville: Westminster John Knox, 2001) 6-7.

3 Cf. J. J. Collins, 'Cult and Culture: The Limits of Hellenization in Judea', Hellenism in the Land of Israel (ed. J. J. Collins and G. E. Sterling; Christianity and Judaism in Antiquity Series 13; Notre Dame: University of Notre Dame, 2001) 38-61 (39).

4 W. C. van Unnik, Tarsus or Jerusalem. The City of Paul's Youth (London: Epworth, 1962) 3-4. 
already quite considerably Hellenized and, on the other, Acts 22.3 cannot be used as proof that Paul grew up in Jerusalem. ${ }^{5}$ We must accept that Tarsus and Jerusalem both played a formative role in his development. Paul should be understood as a complex, multicultural, first-century Mediterranean who integrated various influences into his own person. In a sense, he can be compared to the 'pluralistic person' of the social psychologists. He had what they describe as 'the capacity to accommodate diverse cultural influences so that they become part and parcel of your personal and social self-identity'. ${ }^{6}$ He shared this with countless others in that cultural melting-pot which constituted the Mediterranean basin. In fact, social psychologists assume that 'everyone has the potential to accommodate many kinds of continually changing selves within the self, and actualise these selves within various life contexts' ${ }^{7}$ Paul's letters undeniably reflect such a multicultural aptitude.

\subsubsection{Paul between Ecumenicity and Ethnicity}

What motivated Paul to express himself multiculturally? We should distinguish between his broad theological stance and how he envisioned his own missionary task.

Paul was convinced of the universal scope of the Christian gospel. It must suffice here to call to mind the inclusive character of passages such as Rom 1.16 ; $3.22-24 ; 5.18 ; 11.32 ; 15.7-12 ; 1$ Cor $1.18-25$. And he saw his personal mission as embedded in the universal scope of the gospel. For our purpose it is important to note that, although Paul's correspondence primarily addressed gentile Christians, he would also have kept Jewish Christians in mind. ${ }^{8}$

1 Corinthians 9.19-23 articulates Paul's missionary strategy. The main thrust of his assertion is that he went out of his way to identify with his culturally diverse audiences. He would have done everything possible to find those 'beachheads of identification' ${ }^{\prime 9}$ from where they would be willing to accompany him on his journey of persuasion.

The negative corollary to Paul's rhetoric of inclusivity was the ever-imminent problem of inter-group prejudice. The delicate nature of inter-ethnic relations in general and actual socio-political friction between Jews and non-Jews in this period $^{10}$ indicate that many first century Christian communities found themselves

5 See A. B. du Toit, 'A Tale of Two Cities: “Tarsus or Jerusalem” Revisited', NTS 46 (2000) 375-402.

6 W. Jordaan and J. Jordaan, People in Context (Johannesburg: Heinemann, 3rd ed. 1998) 635.

7 Jordaan and Jordaan, People in Context, 636 (my italics).

8 Cf. L. J. Lietaert Peerbolte, Paul the Missionary (CBET 34; Leuven: Peeters, 2003) 252-6.

9 E. E. White, The Context of Human Discourse. A Configurational Criticism of Rhetoric (Columbia: University of South Carolina, 1992) 216.

10 See, e.g., C. D. Stanley, “"Neither Jew nor Greek”: Ethnic Conflict in Graeco-Roman Society', JSNT 64 (1996) 101-24. 
within a highly explosive situation. ${ }^{11}$ Paul would have done his utmost not to alienate sections of his ethnically diverse audience. Negatively, he would tread lightly where group sensitivities were at stake and, positively, he would accentuate their common Christian identity. ${ }^{12}$

\subsection{The Purpose of this Study}

My purpose is to assess the relevance and implications of the view from 'beyond' by applying it to some selected Pauline themes. What picture emerges from the possible convergence of motifs from divergent cultural backgrounds? I shall restrict myself to two key themes in Pauline soteriology and ecclesiology,

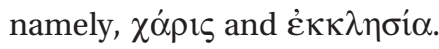

\section{Grace ${ }^{13}$ in Paul}

\subsection{By Way of Introduction}

Grace signifies the theological sense which Paul made of his Damascus experience. It forms the gateway to his soteriology and certainly constitutes a central theological theme in Paul. However, I shall focus only on those aspects pertinent to this enquiry.

\subsection{New Impetus from Hellenistic Research}

The ground-breaking work of Wetter ${ }^{14}$ on the honorific inscriptional material and the magical papyri, followed by the research of scholars such as Danker ${ }^{15}$ and, most recently, that of Joubert ${ }^{16}$ and Harrison, ${ }^{17}$ impacted dramati-

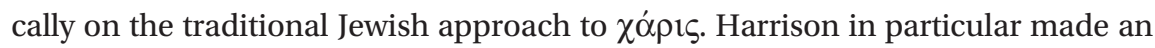
invaluable contribution in this regard. The bearing of the Hellenistic notion of

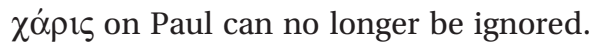

11 M. G. Brett, 'Interpreting Ethnicity', Ethnicity and the Bible (ed. M. G. Brett; Biblical Interpretation Series 19; Leiden/New York: Brill, 1996) 3-22 (9-15).

12 See J. M. G. Barclay, " "Neither Jew nor Greek”: Multiculturalism and the New Perspective on Paul', in Ethnicity (ed. Brett), 197-214 (211-12).

13 'Grace' is used here as a cover-term for a semantic domain which includes $\chi \alpha \dot{\alpha} \rho \varsigma \varsigma$, ع̌ $\lambda \varepsilon \sigma \varsigma$ and

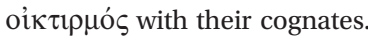

14 G. P. Wetter, Charis. Ein Beitrag zur Geschichte des ältesten Christentums (UNT 5; Leipzig: Hinrichs, 1913).

15 F. W. Danker, Benefactor. Epigraphic Study of a Graeco-Roman and New Testament Semantic Field (St. Louis: Clayton, 1982).

16 S. J. Joubert, Paul as Benefactor: Reciprocity, Strategy and Theological Reflection in Paul's Collection (WUNT 2. Reihe 124; Tübingen: Mohr Siebeck, 2000); 'CHARIS in Paul: An Investigation into the Apostle's Performative Application of the Language of Grace within the Framework of his Theological Reflection on the Event/Process of Salvation', Salvation in the New Testament: Perspectives on Soteriology (ed. J. G. van der Watt; NovTSup 121; Leiden/Boston: Brill, 2005) 187-211.

17 J. R. Harrison, Paul's Language of Grace in its Graeco-Roman Context (WUNT 2. Reihe 172; Mohr Siebeck, 2003). 


\subsection{Xó $\rho ı$ in the Salutatio of Paul's Letters}

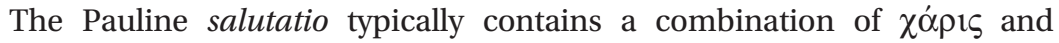

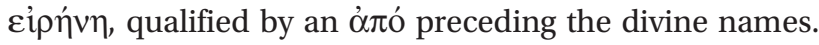

The exact genesis of the Pauline letter greeting is uncertain. ${ }^{18}$ There is a longstanding majority position that Paul's choice of $\chi \alpha$ ápı $\varsigma$ was consciously influenced by the $\chi \alpha$ ipeıv greeting of the traditional Greek letter. ${ }^{19}$ The deft acoustic play between $\chi \alpha$ ípeıv and $\chi \alpha$ ápı may have played a role, but also more fundamental

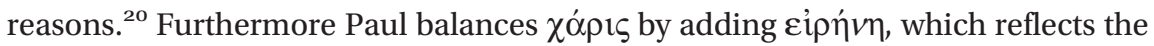
traditional Jewish peace greeting. By substituting $\chi \alpha i p \varepsilon ı v$ with the two nominatives 'grace' and 'peace', the salutatio changed into a wish (may grace and peace be with you) or, more probably, a blessing (grace and peace to you).

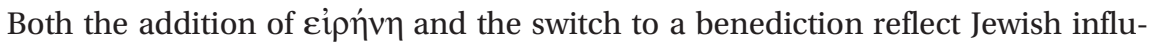
ence. ${ }^{21}$ Early Jewish epistolography ${ }^{22}$ and liturgical conventions come into play. However, this process also may have evolved the other way round, first reflecting

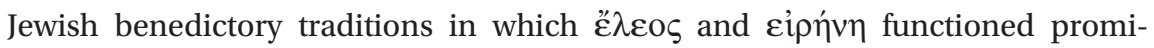
nently, and ending up with the present Pauline salutatio. ${ }^{23}$ In that case, Paul's

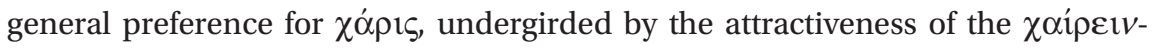
$\chi \alpha$ óp $\varsigma$ word-play - which would certainly have startled and pleased discerning

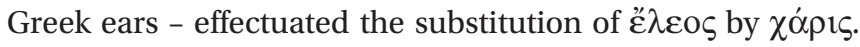

For our enquiry, a decision between these alternatives is of little consequence. Important is the fact that Paul's consistent choice for the dyadic greeting indicates his sensitivity for both Greek and Jewish cultural preferences.

18 But cf. G. A. Gerhard, 'Untersuchungen zur Geschichte des griechischen Briefes I', Philologus 64 (1905) 27-65.

19 Inter alia J. L. White, 'New Testament Epistolary Literature in the Framework of Ancient Epistolography', ANRW II 25/2, 1730-56 (1740); H.-J. Klauck, Ancient Letters and the New Testament. A Guide to Context and Exegesis (English version, with revisions and additions, of Die antike Briefliteratur und das Neue Testament [UTB 2022]) (Waco, TX: Baylor University, 2006) 18-20, 361.

20 Paul loved such acoustic effects. Cf. BDF $\$ 488$. More fundamentally, he would have wanted to replace an epistolary cliché with something meaningful.

21 K. Berger, 'Apostelbrief und apostolische Rede. Zum Formular frühchristlicher Briefe', ZNW 65 (1974) 191-231 (191-207); Klauck, Ancient Letters, 361.

22 For the peace-greeting in Semitic and Jewish letters, see inter alia E. Lohmeyer, 'Probleme Paulinischer Theologie', ZNW 26 (1927) 158-73 (158-64); J. A. Fitzmyer, 'Some Notes on Aramaic Epistolography', JBL 93 (1974) 201-25 (214-16); C. Breytenbach, “"Charis” and "eleos" in Paul's letter to the Romans' (Seminar paper presented at the Colloquium Biblicum Lovaniense 2007; to be published in BETL; used with consent of the author) 1-22 (19-20).

23 This was, in essence, the position of Lohmeyer, 'Probleme', 158-64; recently taken up by Breytenbach, 'Charis', 19-22. 


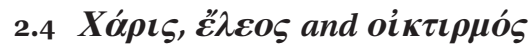

Linguists have often faulted NT scholars for their logo-centrism. Linguistic theory requires that we should rather work with semantic fields. In referring to

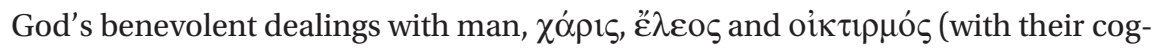
nates) belong to the same semantic field and should therefore be studied together.

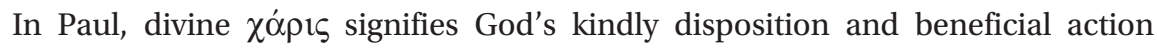
towards undeserving humans. ${ }^{24}$ It can best be translated by 'kindness' or

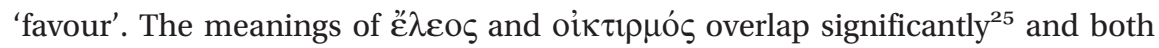

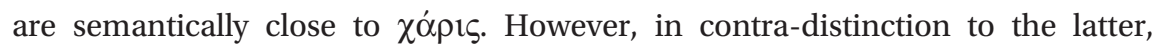
they include a strong element of concern or compassion. ${ }^{26}$ "E $\lambda \varepsilon$ co in Paul could probably best be translated as 'pity' or 'mercy' and oik mercy' or 'compassion'. However, viewed from a diachronic perspective, there

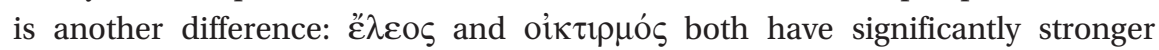

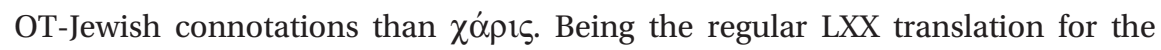
strongly covenantal term Xópıs, in turn, is the regular translation equivalent for $\pi$ and then mostly in the sense of finding favour with someone, especially God. Significantly enough, probably due to Greek influence, the proportional occurrence of $\chi \alpha \dot{\rho} \rho \varsigma \varsigma$ increases in the LXX deutero-canonical literature and the situation is dramatically reversed in Philo ${ }^{27}$ as well as in Paul. ${ }^{28}$

Breytenbach $^{29}$ recently called attention to the importance of the Jewish tradition which depicted God as the compassionate and merciful One. The trajectory of this tradition, or variants thereof, can be followed from LXX Exod 34.6 (cf. 33.19), through the prophets and the Psalms, into early Jewish literature and liturgy (cf. also Luke 1.50, 54, 58, 72, 78). ${ }^{30}$ Paul was certainly

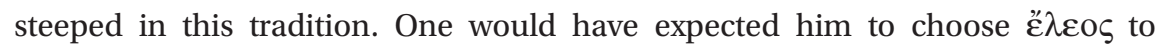
verbalize the benevolence of God. His decision to use $\chi \alpha$ ó due to

24 For Paul, God's grace was much more than a mere positive attitude. It was benevolence in action. Cf. J. D. G. Dunn, The Theology of Paul the Apostle (Edinburgh: T. \& T. Clark, 1998) 322.

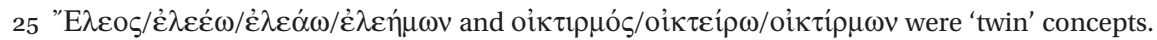
Their concatenation served to strengthen the impact of a statement: LXX Exod 33.19; 4 Kings 13.23; Ps 24.6; 39.11 etc.

26 J. P. Louw and E. Nida, Greek-English Lexikon of the New Testament based in Semantic Domains (2 vols.; New York: United Bible Societies, 1988) 1.751.

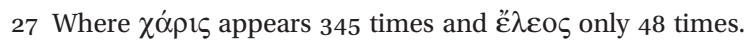

28 In Paul's undisputed letters, $\chi \alpha ́ \rho ı \varsigma, \chi \alpha \rho i \zeta o \mu \alpha ı$ and $\chi \alpha \dot{\rho} 1 \sigma \mu \alpha$, with God as subject, appear at

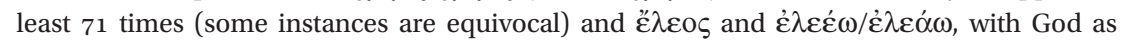
subject, only ten times.

29 'Charis', 6-8. But see also H. J. Stoebe, 'חסד', THAT II 601-4.

30 See Breytenbach, 'Charis', 6-8. 


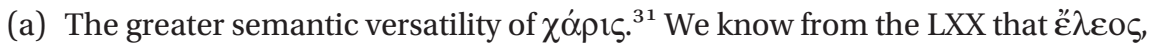
like חסד, could be used reciprocally. ${ }^{32}$ However, its semantic range did not cover 'thankfulness', which did form part of the semantic spectrum of $\chi \alpha \dot{\alpha} \rho \varsigma^{3} .{ }^{33}$

(b) The pervasive use of $\chi \alpha \dot{\rho} \rho \varsigma$ in Hellenistic benefaction.

(c) The critical reserve towards عُ $\lambda \varepsilon \sigma_{\zeta}$ in the Hellenistic intellectual tradition and particularly the radical Stoic attack on the passions. ${ }^{34}$

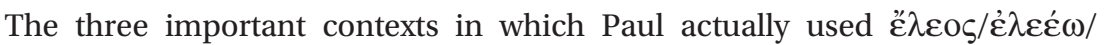
$\dot{\varepsilon} \lambda \varepsilon \alpha \dot{\alpha} \omega$, namely, Rom 9-11; 15.9 and Gal 6.16 are especially revealing. In all three instances, the influence of the OT-Jewish है $\lambda \varepsilon \varsigma_{\zeta}$ tradition, ${ }^{35}$ functioning within a salvation-historical context, ${ }^{36}$ is evident. Romans 9-11 focuses on Israel in the new dispensation: in Rom 9.14-18, غ่ $\lambda \varepsilon \varepsilon \dot{\varepsilon} \omega / \dot{\varepsilon} \lambda \varepsilon \alpha \dot{\alpha} \omega$ occurs four times

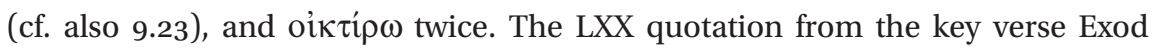
33.19 highlights God's mercy and compassion towards Israel. The Jewish connotations are undeniable. The same is true of Rom 11.30-32. Although the $\dot{\varepsilon} \lambda \varepsilon \dot{\varepsilon} \omega$ word-group, in this case, is used predominantly for God's mercy towards the nations, the broader context focuses on God's universal future for Israel and the nations. In 15.9, है $\lambda \varepsilon \varsigma_{\varsigma}$ appears in a similar salvation-historical context. The same is true of the rather unusual Pauline pronouncement of 'peace and mercy...on the Israel of God' in Gal 6.16.

The situation is, therefore, that Paul regularly used $\chi \alpha \dot{\rho} \rho \varsigma \varsigma$ in view of the fact that the majority of his readers/auditors were Greek-speaking non-Jews. But in contexts where strong Jewish associations and sensitivities were at stake, he pre-

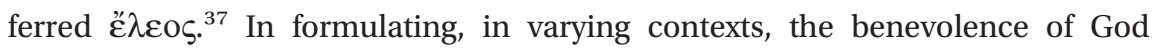
towards undeserving humans, Paul did not hesitate to utilize concepts from both Jewish and Greek cultural storehouses. He moved freely from the one to the other, but did so with sensitivity. Keeping in mind that the majority of his

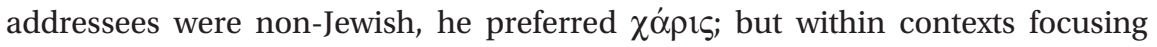
on Israel's religious heritage and future hopes, he applied ع̋ $\lambda \varepsilon o \varsigma$. He did not

31 Harrison, Grace, 287.

32 Stoebe, 'חסד', 600-18.

33 The reciprocal potential of $\chi \alpha$ a $1 \varsigma$ to verbalize both grace bestowed and grace returned

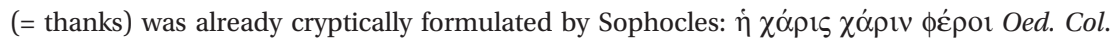

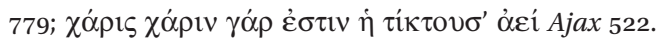

34 See esp. D. Konstan, Pity Transformed (Classical Interfaces; London: Duckworth, 2001). Cf. Apollonius' disdainful dictum, quoted by Cicero: 'nothing dries more quickly than a tear' (Inv. I 109).

35 Breytenbach, 'Charis', 6-16.

36 Already R. Bultmann, Theologie des Neuen Testaments (Tübingen: Mohr Siebeck, 5. Aufl. 1965) 283 pointed to the salvation-historical connotations of ع̌ $\lambda \varepsilon \varsigma_{\zeta}$ in Rom 9-11 and 15.9.

37 Admittedly, there are a few exceptions: Rom 12.8; 1 Cor 7.25; 2 Cor 4.1 and Phil 2.27. 
fuse these two traditions but juxtaposed them, respecting the cultural preferences of both Greeks and Jews, thus also reflecting the inclusiveness of God's grace.

\subsection{Unilateral and Reciprocal}

The qualifications 'unilateral' and 'reciprocal' regularly surface in discussions on grace in Paul. ${ }^{38}$ In theological parlance, the first term indicates the absolute character of God's action over against any human participation, while the second reflects bilateral involvement. This differentiation is then used to contrast the unilateral character of grace in Paul with its reciprocal nature in Hellenism. Although one can appreciate the motive behind this theologoumenon, it is nevertheless misleading. As we shall note, it will be more appropriate to accept that Paul also viewed grace as reciprocal, although he saw the roles within this bilaterality as radically disproportionate. He thought in reciprocal terms, but redefined reciprocity. Reciprocity need not imply commensurality or repayment. It all depends on how reciprocity is defined. Thanking and honouring God is already a form of reciprocity. ${ }^{39}$ Working on a debt of love (Rom $1.14 ; 13.8$ ) is genuinely reciprocal.

In Paul, the dual structure of the grace event is clearly evident in Rom 6.17; 7.25, 1 Cor 15.57 and 2 Cor 2.14. In each case, a graceful action of God calls

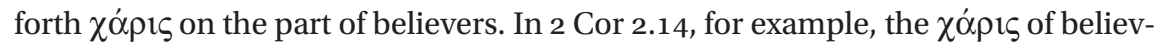
ers is their response to the privilege of sharing in God's triumph.

The two collection chapters (2 Cor 8-9) are in their entirety an exercise in reciprocity. Bilaterality is, for example, clearly active in 8.9: in effect, this artful implicature states, 'In Jesus Christ, God has been so incredibly kind to you; can you find it in your heart not to respond appropriately?' This would have been a real knockover. In 8.13-15, balanced reciprocity, as encapsulated in the iбó $\tau\rceil$ s principle, is also quite evident. Reciprocity is once more active in 2 Cor 9.14-15: the reference

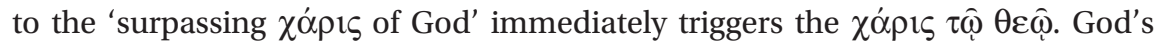
kindness obliges.

A grateful response is not restricted to a 'thank you' or a collection effort. In

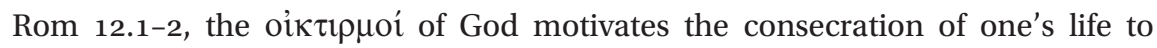
God. Gratitude may also take the form of praise and honouring God. In Rom 11.28-36, the references to God's ع̌ $\lambda \varepsilon \varsigma_{\varsigma}$ elicit a resounding doxology (11.33-36). Similarly, the eulogy in Rom 15.9-12 is a response to God's mercy (15.9).

38 E.g. Dunn, Theology, 322-3; Harrison, Grace, passim.

39 Paul would agree with Graeco-Roman moralists who regarded gratitude as the first essential reaction within the reciprocal cycle: 'He who receives a benefit with gratitude repays his first instalment' (Seneca Ben. II 22). See also S. C. Mott, 'The Power of Giving and Receiving: Reciprocity in Hellenistic Benevolence', in Current Issues in Biblical and Patristic Interpretation (FS M. Tenney; ed. G. Hawthorne; Grand Rapids: Eerdmans, 1975) 60-72 (64). 
The reciprocal character of $\chi \alpha$ ás

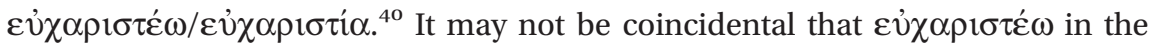
thanksgiving sections of Paul's undisputed letters (except for 2 Corinthians and

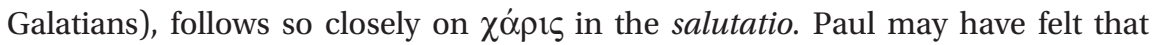
his $\varepsilon \hat{v} \chi \alpha \rho ı \tau \varepsilon \dot{\varepsilon} \omega$ should resonate to the immediately foregoing grace and peace benediction.

What would have influenced Paul to apply the reciprocal character of $\chi \alpha ́ p ı \varsigma$ so effectively? In view of

(a) the strongly reciprocal character of Hellenistic grace;

(b) the pervasiveness of benefaction ideology in the first-century Mediterranean context and

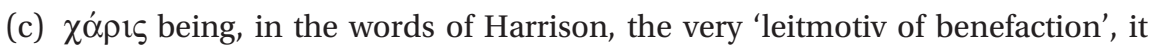
seems obvious that, in Paul's language of grace, he applied the grid of Hellenistic benefaction.

\subsection{The Abundance of Grace, the Augustan Golden Age and the Quinqennium Neronis}

Whenever Paul elaborates on grace, his style tends to 'explode' into language of excess. Most exegetes agree that his eulogy in Rom 5.15-21 on the superabundance of grace draws upon Jewish apocalyptic expectations. ${ }^{41}$ Harrison does not deny Jewish influence, but argues that the reign of grace in Rom 5.12-21 should be equally situated in the Roman eschatology of the Augustan era. ${ }^{42}$

The reign of Augustus was indeed proclaimed and celebrated as the dawning of a golden age, characterized by peace and abundance ${ }^{43}$ - and not without reason, in view of the reform measures of Augustus, the stabilized socio-political situation and the impressive growth in Rome's glory. The initial years of Nero

40 Professor Cilliers Breytenbach first drew my attention to this. Due to shared research interests, we have had several discussions on $\chi \alpha$ ópıs. I wish to thank him for sharing his stimulating insights with me.

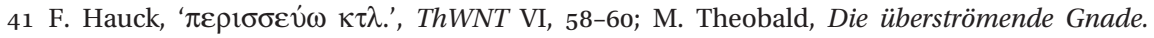
Studien zu einem paulinischen Motivfeld (Bonn: Rheinische Friedrich-Wilhelms-Universität, 1982) 92; M. C. de Boer, The Defeat of Death. Eschatology in 1 Corinthians 15 and Romans 5 (JSNTSup 22; Sheffield: JSOT, 1988) 168-9. For the eschatological abundance motif, cf. Isa 25.6; 27.6; Amos 9.13; Ezek 49.7-12 and particularly 4 Ezra 8.52 (praeparata est habundantia).

42 Harrison, Grace, 227. But see also Danker, Benefactor, 347. R. Jewett, Romans. A Commentary (Hermeneia; Minneapolis: Fortress, 2007) 381, emphasizes the Jewish apocalyptic background of this passage, but also refers to the 'excess of benefaction in the civic cult'.

43 Harrison, Grace, 227-33. See also P. Zanker, The Power of Images in the Age of Augustus (Jerome Lectures, 16th series; Ann Abor: University of Michigan, 1992) esp. 167-238; D. Castriota, The Ara Pacis Augustae and the Imagery of Abundance in Later Greek and Early Roman Imperial Art (Princeton: Princeton University, 1995) esp. 124-69. 
were hailed by optimistic visions of the return of the Augustan golden age. This euphoria was spearheaded by no less than Seneca, acting together with Burrus as mentor for the young incoming princeps. Again, these expectations were not without a measure of justification. ${ }^{44}$ Good governance was initiated. Corruption was combated. The famous pax romana seemed to re-establish itself. What was later called the quinqennium Neronis was remembered as 'the happiest period of the Empire since the death of Augustus' ${ }^{45}$

Paul's description of the bountiful reign of grace may therefore also be profiled against the Roman motif of a dawning golden age. If so, Roman culture enters here as a third factor in Pauline interculturality. We have here a conflation of Jewish and Roman expectations, christologically transformed. ${ }^{46}$

\subsection{Silhouetting Grace in Paul against its Jewish and Hellenistic Backgrounds}

Both the Jewish and the Hellenistic cultural worlds left their imprints on Paul's thinking about grace. We start with his recasting of Hellenistic benefaction motifs.

In comparing grace in Paul with Hellenistic benefaction, it would be unfair to extrapolate some of the latter's most negative manifestations and present them as typical. Certainly, there were many instances of genuine philanthropy on the one hand and sincere gratitude on the other. ${ }^{47}$ However, we cannot ignore contemporary criticism of benefaction practices ${ }^{48}$ and the many indications that they became stereotyped and exteriorized.

The structural correspondence between grace in Hellenistic benefaction and in Paul is evident. Both are reciprocal. Within this reciprocity, $\chi \alpha \dot{\alpha} 1 \varsigma$ indicates both the gift bestowed by the benefactor and the positive reaction of the benefi-

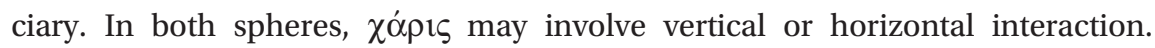

44 B. M. Levick, 'Nero's Quinquennium', Studies in Latin Literature and Roman History (ed.

C. Deroux; Collection Latomus 180; Brussels: Éditions Latomus, 1983) 3.211-25; M. Griffin, Nero: The End of a Dynasty (London: Batsford, 1984) 37-66.

45 W. Sanday and A. C. Headlam, The Epistle to the Romans (ICC; Edinburgh: T. \& T. Clark, 5th ed. 1914) xiv. For the historical uncertainties surrounding this quinqennium, cf. O. Murray, 'The "Quinqennium Neronis" and the Stoics', Historia 14 (1965) 41-61; Levick, 'Nero's Quinquennium'; Griffin, Nero, 37-8, 83-7.

46 For the importance of Christ's death within this context, see de Boer, Defeat, 168.

47 Graeco-Roman moralists tried to put benefaction theory and practice on a loftier level. In his De Beneficiis, Seneca wrote extensively on this. He criticized the do ut des approach and indicated that gift giving has its own intrinsic reward: 'Otherwise it would have been, not a benefaction, but a bargaining' (Ben. II 31.2). Cf. Joubert, Benefactor, 40-50; T. Engberg-Pedersen, 'Gift-giving and God's Charis: Pierre Bourdieu, Seneca in De Beneficiis and Paul in Romans 1-8' (Seminar Paper presented at the 2007 Colloquium Biblicum Lovaniense; used with consent of the author) 4-7, 15-16.

48 Cf., e. g., Mott, 'Power', 67; Zeller, Charis bei Philon, 20-26; and esp. Harrison, Grace, 114-46, 192-209. Significantly, this critique came mainly from Hellenistic-Jewish writers and GraecoRoman moralists. 
In both, gratitude was to be expected of the beneficiary. In both, $\chi \alpha \dot{\alpha} 1 \varsigma$ on the part of the beneficiary could be in the form of or complemented by praise or the bestowal of honour. This correspondence undeniably indicates that Paul was significantly influenced by Hellenistic benefaction conventions. Only when we delve deeper, differences become manifest.

The first and most obvious difference is that, contrary to the mostly material and often socio-political connotations of grace in Hellenistic benefaction, grace in Paul is constantly religious in character. The source of all grace is

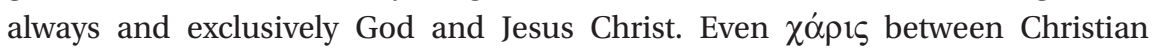
communities (2 Cor 8-9) rests on the basis of God's grace. ${ }^{49}$ At the same time, it primarily addresses humanity's religious needs, particularly the remission of $\sin ^{50}$

The second difference is that of motivation. Whereas God's grace is totally unconditional, Hellenistic benefaction was to an important extent governed by the do ut des principle. Would-be benefactors would consider what return they could get from their beneficence - whether in the form of loyalty, power, honour or material benefits. Benefaction was often regarded as a kind of loan. ${ }^{51}$ It was therefore only natural to select those beneficiaries who were able to make a worthwhile counter-gesture. According to Paul, God offered his grace free of any condition or expectation of repayment (Rom 3.24; 5.15-17). He offers it to rebels who bereaved him of his honour (Rom 1.21, 23, 25 etc.). His motivation was not the do ut des principle. It was divine love which prompted him to extend grace towards the godless (Rom 5.6-11). ${ }^{52}$

A third difference was the contingent and precarious character of Hellenistic benefaction. It depended on the changing fortunes and whims of benefactors, including the gods, ${ }^{53}$ while Christian grace, as Paul defines it, is a constant life experience. Hence he can speak of 'this grace in which we stand' (Rom 5.2). Christian life exists under the dominion of grace (Rom $5.17-21 ; 6.15$ ). Grace is a power which escorts and protects. ${ }^{54}$

Regarding the Jewish roots of grace, the apostle took up the basic Jewish tradition of the kindness and mercy of Yahweh which flows like a broad stream through the entire OT and the early Jewish period and which would have been

49 Joubert, Benefactor, 136-7, 178-80.

50 In Hellenism, the beneficence of the gods usually took the form of concrete favours - cf. Joubert, 'CHARIS in Paul', 188. They did not provide for salvation beyond death, the mystery religions being the only exception - H. Dörrie, 'Gnade A I-II', RAC XI 331-3.

51 Mott, 'Power', 61; Zeller, Charis bei Philon, 14.

52 H. Schlier, Der Römerbrief (HThKNT VI; Freiburg/Basel/Wien: Herder, 1977) 153, calls this grace 'staunenswert...ohne jegliche Analogie'.

53 Cf. Konstan, Pity, 124 (also 105-16).

54 Zeller, Charis bei Philon, 133. 
most positively received by him. God is never obliged to bestow grace ${ }^{55}$ - not initially, and also not as a result of manifestations of gratitude on the part of believers. ${ }^{56}$ He bestows grace for reasons of his own. At decisive points Paul radically transcends the ethos of Hellenistic benefaction. Love as the motivation for God's action (Rom 5.8) is Jewish to the core.

Most importantly, christology was the diagnostic feature which decisively distinguished grace in Paul from Hellenistic grace. In all of Paul's closing benedictions, $\chi \alpha \dot{\rho} \rho \varsigma \varsigma$ is followed by a genitive of origin, identifying Jesus Christ the Lord as its source. And being christological, all Pauline grace is grace of the cross. ${ }^{57}$

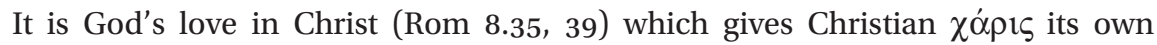
special proprium.

\subsection{Conclusion}

Paul is sensitive to differentiate between Jewish and Greek traditions. In his letter-greetings, he respects the cultural conventions of the two main constituen-

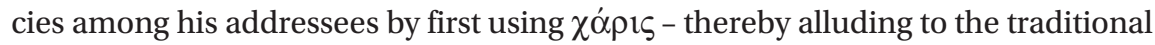
Greek greeting - and then coupling it with the typical Jewish peace salutation, both reinterpreted from and integrated into a Christian perspective. Elsewhere

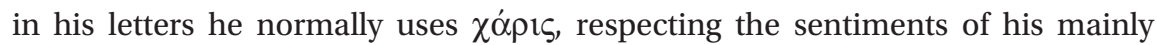
non-Jewish addressees; but where Jewish salvation-historical associations inter-

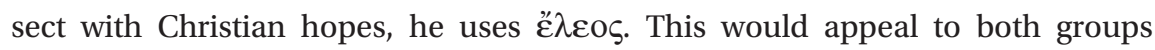
across the cultural divide.

In his communication of grace, he applies all the linguistic and socio-cultural tools available to him. He takes up the OT-Jewish concept of God as the compassionate and merciful One, merges it with the basic structure and linguistic apparatus of Hellenistic benefaction and sends it through the christological prism. Thus both heritages are transformed. Jesus is now the agent and source of grace. And, most importantly, moving through this christological filter, grace acquires a cruciform shape.

\section{Ecclesia}

\subsection{Introductory Remarks}

The roots of the NT $\dot{\varepsilon} \kappa \kappa \lambda \eta \sigma i \alpha$ concept have been hotly debated. Recently Ferdinand Hahn stated confidently that this bone of contention has at last been resolved, ${ }^{58}$ but many will disagree with him.

55 Cf. the repeated combination of $\delta \omega \rho \varepsilon \alpha(v)$ with $\chi \alpha \dot{\alpha} \rho \varsigma$ to emphasize the unsolicited, free character of grace (Rom $3.24 ; 5.15,17$ ).

56 In his excellently documented article, Mott, 'Power', amply demonstrated how original donors, including the gods, were obligated to continue their generosity when fitting gratitude was bestowed (esp. 63-7).

57 Rom 5.1-11 and esp. vv. 6-8; 5.15-20; 8.32.

58 F. Hahn, Theologie des Neuen Testaments (2 vols.; Tübingen: Mohr Siebeck, 2002) 2.480. 
In the search for the roots of the NT $\dot{\kappa} \kappa \kappa \eta\rceil \sigma i \alpha$, the either/or bias is often glar-

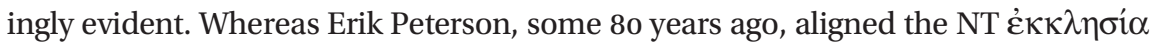
with the meetings of the Greek $\delta \eta \mu \mathrm{\jmath},{ }^{59}$ Leonhard Rost declared categorically that Jesus derived the word and concept of $\dot{\kappa} \kappa \kappa \eta \eta \sigma i \alpha$ from the OT. In appropriating $\dot{\varepsilon} \kappa \kappa \lambda \eta \sigma i \alpha$, the early church expressed its conviction to be the new Israel, the true people of God. ${ }^{60}$ Instead of even considering that the Greek notion of

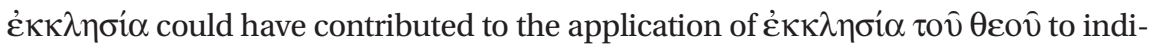
vidual churches, Rost resorted to a theological argument. ${ }^{61}$

Peterson and Rost represent two extremes. More recent studies show a greater openness towards bridging the divide. Klaus Berger's position is commendably

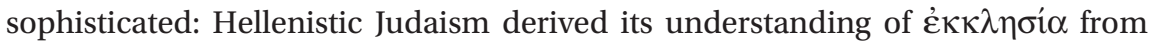
the provincial and monarchic manifestations of $\dot{\kappa} \kappa \kappa \lambda \eta \sigma i \alpha$ in Hellenism, and, subsequently, Hellenistic Jewish Christianity, although it borrowed the name

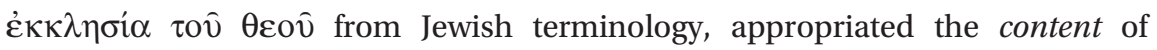
$\dot{\varepsilon} \kappa \kappa \lambda \eta \sigma i \alpha$ from Hellenistic Judaism. ${ }^{62}$ But here also the lady's slip is showing. Although Berger is much more nuanced than Peterson, his work still reveals a predisposition towards minimizing the effect of Israelite-Jewish traditions. ${ }^{63}$ A third position is that of Schrage. ${ }^{64}$ He does not deny some influence on the part of the LXX; however, he is convinced that $\dot{\kappa} \kappa \kappa \lambda \eta \sigma i \alpha$ early Christian creation. But let us move in medias res.

\subsection{The Pauline Spectrum}

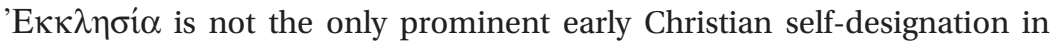
Paul. Ayror is also quite conspicuous. ${ }^{65}$ Paul applies these two designations so self-evidently that most researchers agree that they originated from pre-Pauline Christianity. I shall argue that the $\dot{\varepsilon} \kappa \kappa \lambda \eta \sigma i \alpha$ title originated within Greek-speaking early Christian circles in Jerusalem, spreading from there to Antioch.

In Paul, the semantic range of $\dot{\varepsilon} \kappa \kappa \lambda \eta \sigma i \alpha$ covers the following:

1 The event of a (congregational) meeting, as in 1 Cor 11.18; 14.19, 28, (34, 35 Pauline authorship disputed).

59 E. Peterson, Die Kirche (München: Beck, 1929) 14-15 and nn. 18-19.

60 L. Rost, Die Vorstufen von Kirche und Synagoge im Alten Testament (BWANT 4. Folge Heft 24; Stuttgart: Kohlhammer, 1938) esp. 154.

61 Rost, Die Vorstufen von Kirche und Synagoge, 155.

62 K. Berger, 'Volksversammlung und Gemeinde Gottes. Zu den Anfängen der christlichen Verwendung von "ekklesia" ', ZThK 73 (1976) 167-207 (171-84, 186, 204, 206).

63 According to him the evidential basis for connecting the NT $\dot{\kappa} \kappa \kappa \lambda \eta \sigma i \alpha$ with Israel of the desert period is too small ('Volksversammlung', 185; cf. 'Kirche II. Neues Testament', TRE XVIII 214). 64 W. Schrage, ' "Ekklesia” und "Synagoge”. Zum Ursprung des urchristlichen Kirchenbegriffs', ZThK 60 (1963) 178-202.

65 Occurring 25 times. 
2 An entity in the sense of a local congregation. The bulk of Pauline occurrences fall within this category. ${ }^{66}$

3 In a few instances, to which we shall return later, Paul may be referring to the supra-local, that is, the universal church, of which the individual churches are local manifestations.

Bearing this Pauline spectrum in mind, let us now pay attention to $\dot{\varepsilon} \kappa \kappa \lambda \eta \sigma i \alpha$ in the $\mathrm{LXX}^{67}$ and in the writings of Philo.

\subsection{Ecclesia in the LXX and Philo - A Broad Overview ${ }^{68}$}

\subsubsection{Ecclesia in the LXX}

The unmarked meaning of $\dot{\varepsilon} \kappa \kappa \lambda \eta \sigma i \alpha$ in Greek is the event of 'coming together', a 'meeting'. Within various contexts, this event can then become more specific, for instance, as a political or religious assembly. In the LXX, the

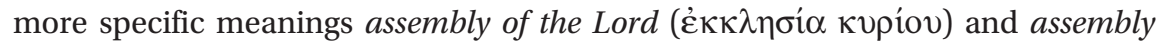
of Israel, particularly in the form of the prolifically used whole assembly of Israel $(\pi \hat{\alpha} \sigma \alpha \dot{\varepsilon} \kappa \kappa \lambda \eta \sigma i \alpha$ 'I $\sigma \rho \alpha \eta \dot{\lambda}),{ }^{69}$ are especially relevant. Since in old Israel we cannot divide the religious from the political, both specified meanings refer to the same assembly: the one being qualified from its divine perspective, the

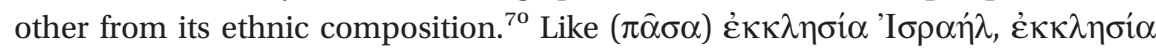
кupíov was an inclusive, supra-local term, embracing the entire people of God.

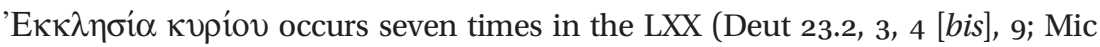

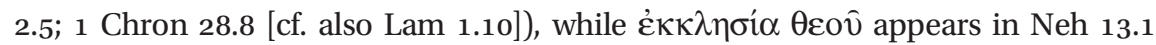

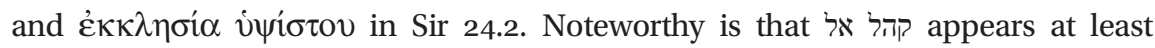
twice in the Qumran documents (1QSa 2.4; 1QM 4.10)..$^{71}$ However, the presence of the $\dot{\varepsilon} \kappa \kappa \lambda \eta \sigma i \alpha$ кupíov motif is not restricted to those instances where the divine genitive specifically indicates that the $\dot{\varepsilon} \kappa \kappa \lambda \eta \sigma i \alpha$ is the assembly of the

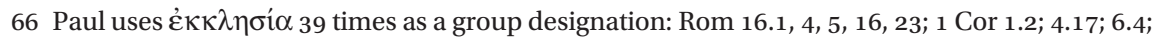
7.17; 10.32; 11.16, 22; 12.28; 14.4, 5, 12, 23, [33]; 15.9; 16.12, 19 (bis); 2 Cor 1.1; 8.1, 18, 19, 23, 24; 11.8, 28; 12.13; Gal 1.2, 13, 22; Phil 3.6; 4.15; 1 Thess 1.1; 2.14; Phlm 2. The bulk of these refer to local congregations (three of the latter to house churches: Rom 16.5; 1 Cor 16.19; Phlm 2).

67 I purposefully chose the LXX as point of departure since the choice for $\dot{\kappa} \kappa \kappa \lambda \eta \sigma i \alpha$ most likely originated within the pre-Pauline Greek-speaking Christian movement.

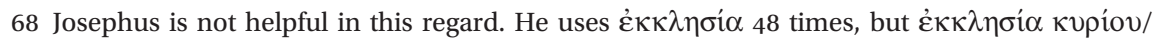

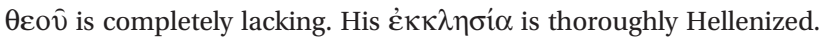

69 Or small variations: Deut 31.30; Josh 9.2-3; 3 Kings 8.14, 22, 55; 12.3 (A); 1 Chron 13.2, 4; 2 Chron 6.3 (bis) etc.

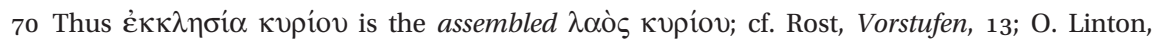
'Kirche I. Bedeutungsgeschichtlich', RAC IV 907-11.

71 Professor Elisha Qimron, co-editor of 4Q396 (see E. Qimron \& J. Strugnell, Qumran Cave $4 \mathrm{~V}$ [DJD 10; Oxford: Clarendon, 1994]), also known as 4QMMT ${ }^{\mathrm{c}}$ - informed me that 4Q396 1-2i (line 40) may also have contained the phrase קהזל אל (There is a lacuna after.) 


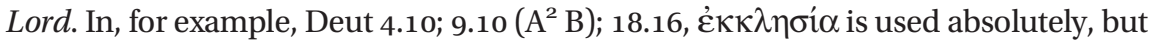
the divine genitive is implied. ${ }^{72}$ It should also be kept in mind that, originally, the

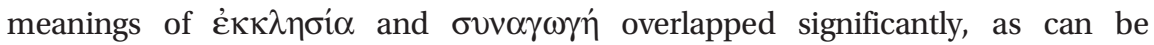

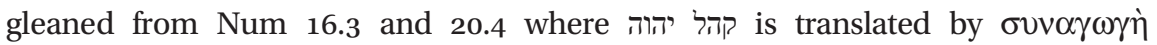

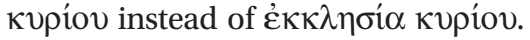

There is an intriguing aspect to the semantic development of $\dot{\varepsilon} \kappa \kappa \lambda \eta \sigma i \alpha$ кupíov. In Deut 23, where this phrase occurs five times, several entry conditions are stipulated. It seems likely that $\dot{\varepsilon} \kappa \kappa \lambda \eta \sigma i \alpha$ is here understood as a closed group with boundary markers and entrance requirements. The $\dot{\varepsilon} \kappa \kappa \lambda \eta \sigma i \alpha$ is becoming an entity which is not restricted to the occasion of the meeting event, but outlives it. This becomes even clearer in the tradition emanating from Deut 23. In Neh 13.1-3, separating those of foreign descent from the $\dot{\varepsilon} \kappa \kappa \lambda \eta \sigma i \alpha$ actually means excommunication from the people of Israel. The $\dot{\varepsilon} \kappa \kappa \lambda \eta \sigma i \alpha \kappa v \rho i ́ o v$ is no longer a one-off assembly; it has acquired a permanent existence of its $\mathrm{own}^{73}$ and the meeting-aspect has become supplementary. The same may be true of Lam 1.10. In 1QSa 2.4 and 4Q396 1-2i line 40, this Deuteronomic tradition surfaces again. In both instances קהל most probably refers to the congregation of Qumran. Regarding the second text, Fabry is of the opinion that קהל functions as a fully fledged self-designation for the Qumran community ${ }^{74}$ (cf also CD 7.17).

Contrary to this line of thought, Berger categorically states that, before the NT,

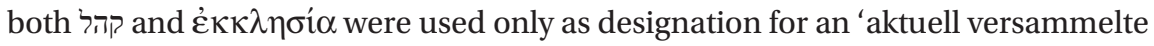
Gemeinschaft' ${ }^{75}$ It is not clear how Berger can concede that we do find evidence of 'generelle Kriterien von Gruppenmitgliedschaft' in the unfolding of the Deut 23 tradition ${ }^{76}$ but still persist in denying that before the NT קהל 'Gruppenbezeichnung'. One is inclined to ask how a group designation could be imagined without a group. ${ }^{77}$

The work of Jesus Ben Sirach requires special attention since this document bears important marks of interculturality. Searching for the happy medium

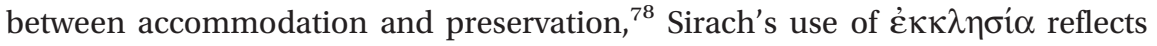
a striking amalgam of Greek and Jewish patterns:

72 See F.-L. Hossfeld, 'Gottesvolk als Versammlung', in Unterwegs zur Kirche. Alttestamentliche Konzeptionen (ed. J. Schreiner; QD 110; Freiburg/Basel/Wien: Herder, 1987) 130-1. Cf. also Judg 20.2.

73 As nowadays in 'Assemblies of God' the focus is not on the event of meeting but on a church.

74 H.-J. Fabry, 'קהל qahal V', ThWAT VI 1219-20.

75 'Volksversammlung', 187, 188.

76 'Volksversammlung', 190; cf. also K. Berger, 'Kirche II. Neues Testament', TRE XVIII 215. He even affirms that in 4 QFlor 1 , where Deuteronomy 23 is taken up once more, we have a group designation ('Volksversammlung', 189).

77 This inconsistency was also noticed by H. Merklein, 'Die Ekklesia Gottes. Der Kirchenbegriff bei Paulus und in Jerusalem', $B Z 4$ (1979) 48-70 (60-2).

78 Cf. T. Middendorp, Die Stellung Jesu Ben Siras zwischen Judentum und Hellenismus (Leiden: Brill, 1972). 
1 Sirach basically has the meeting of a Greek $\delta \hat{\eta} \mu \mathrm{s}$ in mind. Nevertheless, the Jewish theocratic idea is not yet abandoned. ${ }^{79}$ This is clear from 24.2, where

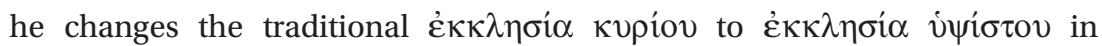
order not to offend Greek-oriented readers. ${ }^{80}$

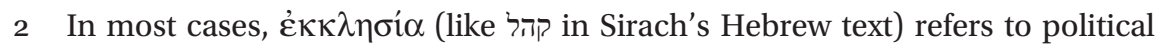

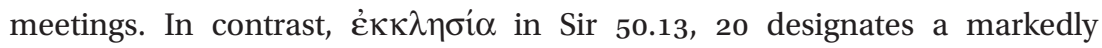
cultic occasion. ${ }^{81}$ However, in the Jerusalem of ca. 200 BCE where the local authorities were also a priestly aristocracy, we should not differentiate too strictly between political and religious meetings. ${ }^{82}$ It would therefore be risky to identify the $\dot{\varepsilon} \kappa \kappa \lambda \eta \sigma i \alpha$ of Sir 24.2 as a purely political meeting. The fact that it is called an $\dot{\varepsilon} \kappa \kappa \lambda \eta \sigma i \alpha \dot{v} \psi i \sigma \tau o v$ rather points towards a primarily religious occasion. It is significant that here, under Greek influence, the term which traditionally had an inclusive, supra-local connotation, now

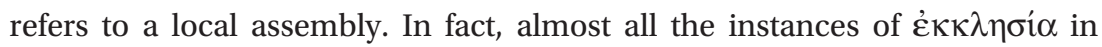
Sirach indicate local assemblies. ${ }^{83}$

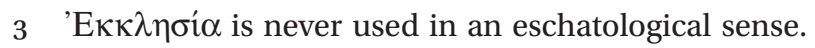

\subsubsection{Philo}

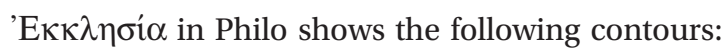

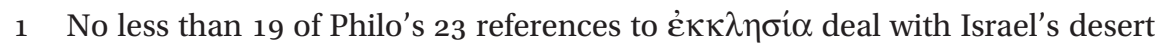
traditions. ${ }^{84}$ Hermeneutically, he actualizes these in favour of his philosophical argument.

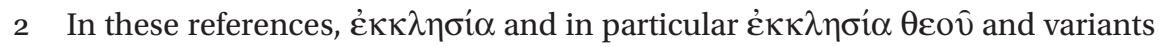
thereof are self-evident designations. They have a cultic connotation and are (almost) always inclusive. The only instance where $\dot{\varepsilon} \kappa \kappa \lambda \eta \sigma i \alpha$ indicates a local congregation is Virt. 108: 'And if any of them (scil. the Egyptians) should wish

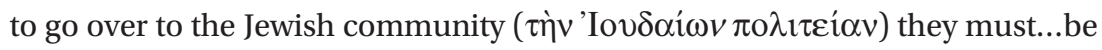
favoured in such a way that the third generation is invited to the congregation

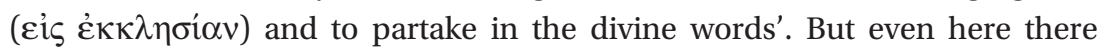

79 Middendorp, Stellung, 158.

80 Middendorp, Stellung, 62, 184. Avoidance of the Yahweh name also contributed to this (cf. Neh 13.1 and Qumran).

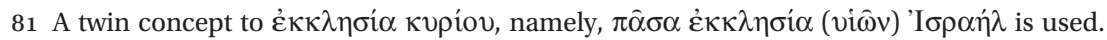

82 Cf. Middenddorp, Stellung, 140-55; N. A. Dahl, Das Volk Gottes. Eine Untersuchung zum Kirchenbewusstsein des Urchristentums (Darmstadt: Wissenschaftliche Buchgesellschaft, 2. Aufl. 1963) 63-4.

$8315.5 ; 21.17 ; 23.24 ; 24.2 ; 30.27(33.18) ; 34(31) .11 ; 38.33 ; 39.10 ; 44.15 ;$ in 26.5 an 'unruly multitude'.

84 Exodus references are: Dec. 32, 45; Her. 251; Post. 143. Direct or indirect references to Deuteronomy 23 are: Conf. 144 (bis); Deus 111; Ebr. 213 (bis); Leg. 3.8, 81(bis); Migr. 69; Mut. 204; Post. 177; Somn. 2.184, 187; Spec. 1.325; Virt. 108. Of these, five contain direct quotations from Deut 23: Conf. 144; Ebr. 213; Leg. 3.81; Post. 177; Somn. 2.184; cf. Virt. 106. 
seems to be a correlation between the local Jewish community and the Jewish

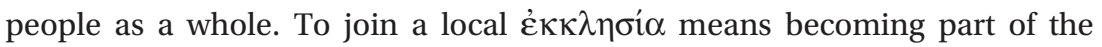
Jewish people.

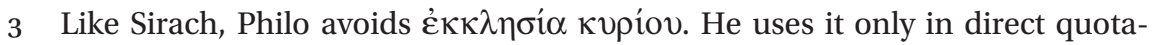
tions from Dtn 23 (Leg. 3.81; Post. 177; Ebr. 213; Conf. 144). Otherwise he

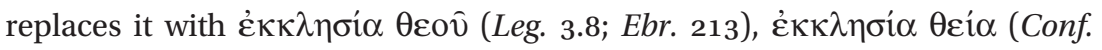

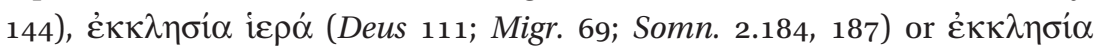

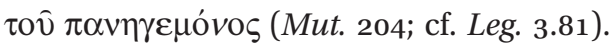

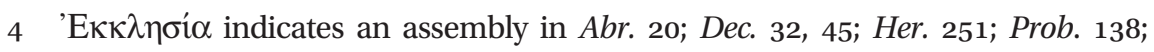
Spec. 1.325; 2.44. Of these, Abr. 20; Prob. 138 and Spec. 1.325; 2.44 refer to

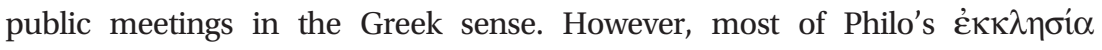
statements referring to Deut 23 seem to have the congregation of Israel in mind. ${ }^{85}$ Berger also accepts unequivocally that in Virt. 108 Philo refers to a community - the parallelism between $\pi$ o $\lambda \iota \tau \varepsilon i \alpha$ and $\dot{\varepsilon} \kappa \kappa \lambda \eta \sigma i \alpha$ being obvious. ${ }^{86}$

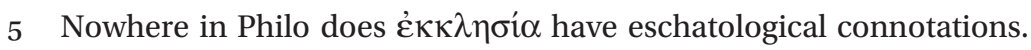

\subsubsection{Resumé}

The upshot of this overview is the following:

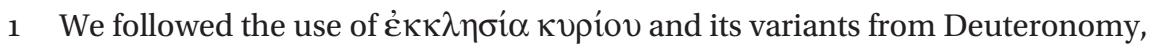
through Mic 2.5; Lam 1.10, 1 Chron 28.8, Neh 13.1, Sirach and Philo, also including some significant references to Qumran. ${ }^{87}$ 'Assembly of the Lord', although not used prolifically, was a persistent and meaningful concept which stayed alive in the collective consciousness of the Jewish people well into the NT era. It was a precious part of Israel's heritage, which rekindled perceptions of a pristine, foundational period when they were established as a nation, chosen by and holy unto Yahweh.

2 The tendency to substitute the genitive кupíov by means of other divine qualifications first appeared in Neh 13.1 (cf. Qumran) but then also in Sir 24.2 and very prominently in Philo. In the case of Sirach and Philo, not only avoidance of the tetragrammaton, but also Greek influence would have played a role.

3 Although $\dot{\varepsilon} \kappa \kappa \lambda \eta \sigma i \alpha$ normally focused on the meeting event, there are a number of instances, particularly in the Deut 23 tradition, where the focus

85 Notably Conf. 144 (bis); Deus 111; Ebr. 213 (bis); Leg. 3.81 (bis); Migr. 69; Mut. 204; Post. 177; Somn. 2.184, 187. Conceded by Berger, 'Volksversammlung', 189-90.

86 Berger, 'Volksversammlung', 190: 'Der entscheidende Schritt ist damit getan.'

87 However, the argument that the Christian adoption of $\dot{\kappa} \kappa \kappa \lambda \eta \sigma i \alpha$ derived exclusively from apocalyptic Judaism as manifested in Qumran (K. Stendahl, 'Kirche II. Im Urchristentum', $R G G^{3}$ III 1298-9 and especially J. Roloff, Die Kirche im Neuen Testament [GNT 10; Göttingen: Vandenhoeck \& Ruprecht, 1993] 83; EWNT I 1000) atomizes a much longer tradition and has a very slender documentary basis. 
shifted to the group who attended these meetings. The shift from a meeting to a group, from assembly to congregation, was obviously not that dramatic.

4 Originally $\dot{\varepsilon} \kappa \kappa \lambda \eta \sigma i \alpha$ кvpíov was an inclusive, supra-local term, referring to the entire people of God. In contrast, due to Greek influence, Sirach uses $\dot{\varepsilon} \kappa \kappa \lambda \eta \sigma i \alpha$ in a local sense. This is also the case in Philo Virt. $108 .^{88}$

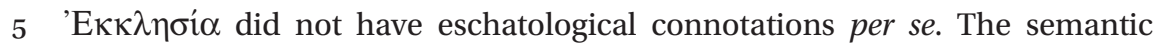
overloading of OT motifs is a pertinent example of what James Barr dubbed

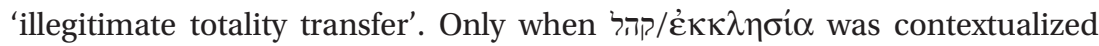
into a broader, eschatological framework, as in Qumran, did it acquire eschatological connotations.

\subsection{Ecclesia in the Pre-Pauline Jesus Movement}

\subsubsection{Finding a name}

For the Jesus movement, the initial period was one of self-definition. In their search to express their identity and to describe their religious 'home' within or alongside Jewry, ${ }^{89}$ the early Christians adopted a variety of names such as 'disciples', 'holy ones', 'brothers', 'the elect', '(followers of) the Way', 'Christians'. ${ }^{90}$ The function of these names was to reveal something typical and/or positive (honorific, inspirational) about the new movement. ${ }^{91}$

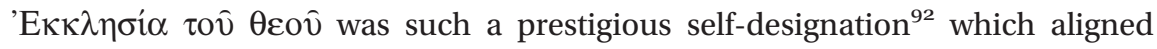
the Jesus movement with the coveted tradition of Israel as the people of God..$^{93}$

\subsubsection{Why ecclesia tou theou and not ecclesia kuriou?}

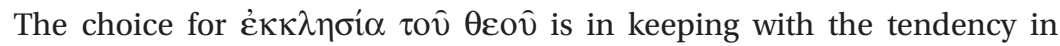
Jewish sources to replace the tetragrammaton with other divine titles. ${ }^{94}$

88 W. Schrage showed how synagoge followed the same route: From an originally inclusive term,

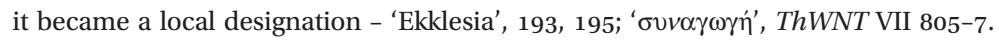

89 For the same process in Qumran, cf. Müller, 'qahal', 618. H. Braun, Qumran und das Neue Testament (2 vols.; Tübingen: Mohr Siebeck, 1966) 2.146-9, compares the two processes.

90 Cf. W. G. Kümmel, Kirchenbegriff und Geschichtsbewusstsein in der Urgemeinde und bei Jesus (Göttingen: Vandenhoeck \& Ruprecht, 2. Aufl. 1968) 16-9; W. Schenk, 'Die ältesten Selbstverständnisse christlicher Gruppen im ersten Jahrhundert', ANRW II 2/2, 1357-467; Roloff, Kirche, 82-3.

91 These in-group designations should be distinguished from derogatory nicknames originating from opposition groups and which were in certain instances appropriated as honorific.

92 In 1QM 4.10 'assembly of God' is one of several prestigious and inspiring insignia on the war banners of the community.

93 Pace, inter alia, Dahl, Volk Gottes, 267-76; Merklein, 'Ekklesia Gottes', 62-63; Dunn, Theology, 537-43; Hahn, Theologie, II 480-1; T. Söding, 'Ekklesia und Koinonia. Grundbegriffe paulinischer Ekklesiologie', Catholica 2 (2003) 111-12.

94 This agrees with the NT tendency to replace kyrios, in referring to God, by theos. Whereas in the LXX the ratio of kyrios to theos is roughly 2:1, it is in the NT (excluding quotations) roughly 1:40. 


\subsubsection{Why ecclesia and not synagoge?}

Schrage proved the fallacy of playing off these two terms against one

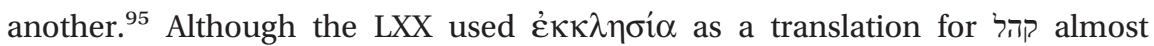
twice as often as $\sigma v v \alpha \gamma \omega \gamma \eta \eta^{96}$ there seems to be, theologically speaking, no convincing reason why the one was preferred to the other. Although Schrage's own theory for the choice of $\dot{\varepsilon} \kappa \kappa \lambda \eta \sigma i \alpha$ has not been found convincing, ${ }^{97}$ he was nevertheless correct in arguing that the choice for $\dot{\kappa} \kappa \kappa \lambda \eta \sigma i \alpha$ should rather be sought in first-century group dynamics. At this stage, the synagogue system was already well established. The Jesus followers needed a name that would not only express their belief that they were the rightful heirs of the precious convictions, values and hopes of Israel, but also distinguish them from contemporary Judaism. For the emerging Christian movement blatantly to claim to be the 'synagogue of God' would be to invite confrontation. Therefore $\dot{\varepsilon} \kappa \kappa \lambda \eta \sigma i \alpha$ was an obvious choice.

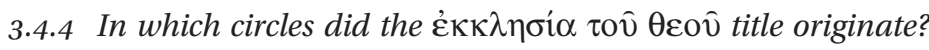

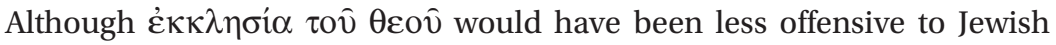
ears, the claim to such a coveted title was still a drastic one. It should therefore rather be ascribed to the 'Hellenists', that is, the (more progressive) Greek-speaking Christian Jews ${ }^{98}$ in Jerusalem, than to the theologically conservative so-called 'Jewish Christians' ${ }^{99}$ Having originated in Jerusalem, ${ }^{100}$ it would have spread to Antioch and elsewhere.

\subsubsection{Concluding remarks about ecclesia in the pre-Pauline Hellenistic church}

1 Like other early Christian titles, and in keeping with its traditional use,

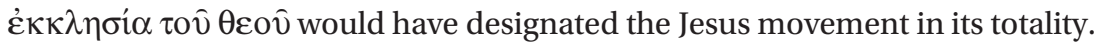
However, the need to identify individual churches would arise when the Jesus movement settled in multiple locations. We already noted how Ben Sirach adapted to the Greek convention of using $\dot{\varepsilon} \kappa \kappa \lambda \eta \sigma i \alpha$ for a local assembly. Likewise, the pervasive presence of Greek $\dot{\varepsilon} \kappa \kappa \lambda \eta \sigma i \alpha$ would have induced

95 See Schrage 'Ekklesia', 189-94.

96 Roloff's statement (Kirche, 83 n. 67) that the LXX preferred to translate qahal with synagoge is

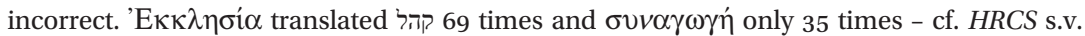

97 His argument was that the 'Hellenists' could not identify with the centrality of the law in the synagogue.

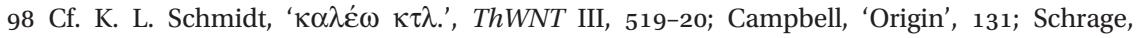
'Ekklesia', 198; M. Hengel, 'Zwischen Jesus und Paulus', ZThK 72 (1975) 201. For the theological position of the 'Hellenists', see Schrage, 'Ekklesia', 196-200; H. Räisänen, 'Die "Hellenisten" der Urgemeinde', ANRW II 26.2 1502-3.

99 It is scarcely by accident that the only NT reference to a Christian synagogue occurs in James 2.2.

100 It cannot be absolutely ruled out that, similar to Qumran, already the Aramaic-speaking church may have called itself the קהלא/קהל אל, but this is less likely. 
early Christians to apply this title to individual churches. ${ }^{101}$ Once again we have to reckon with a confluence of Jewish and Greek ideas: the Jewish heritage manifesting itself in envisaging the $\dot{\varepsilon} \kappa \kappa \lambda \eta \sigma i \alpha$ as an inclusive, supra-local entity, Greek convention manifesting itself in the application of this title to local churches. There was another facilitating factor: theologically speaking, the divine genitive indicated that there was no essential difference between the ecumenical $\dot{\varepsilon} \kappa \kappa \lambda \eta \sigma i \alpha$ and an individual one. ${ }^{102}$

2 As we have seen, the early Christians were not the first or unique in implementing the semantic shift in $\dot{\varepsilon} \kappa \kappa \lambda \eta \sigma i \alpha$ towards a group. However, they implemented this transition on a much grander scale.

3 The Christian innovation also did not lie primarily in their claim to be the $\dot{\varepsilon} \kappa \kappa \lambda \eta \sigma i \alpha$ ation with Jesus Christ which differentiated them from other $\dot{\kappa} \kappa \kappa \lambda \eta \sigma i \alpha \iota$ and which qualified their existence as eschatological.

\subsection{Back to ecclesia in Paul}

\subsubsection{A bird's-eye view}

In Jerusalem or Antioch Paul would have become acquainted with the

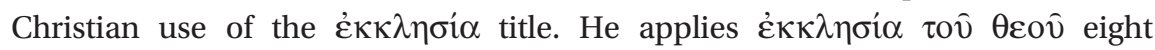
times, ${ }^{103}$ but the divine genitive is implied in all his references to $\dot{\varepsilon} \kappa \kappa \lambda \eta \sigma i \alpha$ as an institution. References to local churches dominate overwhelmingly. ${ }^{104}$ This is perfectly understandable in light of his pioneering pastoral work. Hellenistic convention would undoubtedly have acted as a catalyst in this process of individualization.

Nevertheless, there probably are a few exceptions. Reflecting on his past in

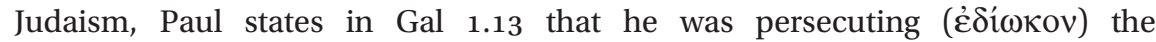

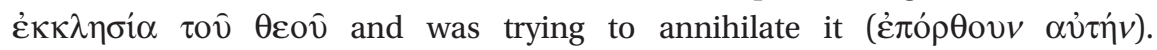
Significantly enough he then spells out this single entity (cf. $\alpha v^{\tau} \eta^{\prime} v$ ) as consisting of the congregations in Judea (1.22-24). Through his action against the congregations in Judea he aspired to exterminate the church of God in its entirety. ${ }^{105}$

101 The self-evident way in which Paul applied this term to local congregations indicates that he inherited it.

102 Recently M. Wolter, 'Von der Entmachtung des Buchstabens durch seine Attribute', Sprachgewinn. Festschrift für Günter Bader (ed. H. Assel and H.-C. Askani; Arbeiten zur Historischen und Systematischen Theologie 11; Münster: Lit-Verlag, 2008) 149-61 (155-60), drew attention to the far-reaching semantic implications of this genitive in Paul. I would like to thank him for his thought-provoking insights which he kindly shared with me. 1031 Cor 1.2; 10.32; 11.16, 22; 15.9; 2 Cor 1.1; Gal 1.13; 1 Thess 2.14; cf also Acts 20.28.

104 Of the 39 instances of $\dot{\varepsilon} \kappa \kappa \lambda \eta \sigma i \alpha$ as a Christian self-designation (cf. n. 66), at least 31 refer to local congregations.

105 J. Hainz, Ekklesia. Strukturen paulinischer Gemeinde-Theologie und Gemeinde-Ordnung (BU

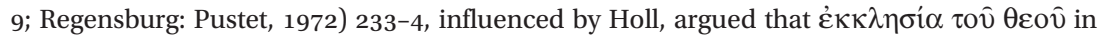


Evidently Paul saw a direct correlation between the church as a whole and the concrete, local churches. Both essentially belong together, being qualified by the divine genitive. In 1 Cor 12.28, he uses a statement about the ecumenical church (cf. the 'apostles') to bring home how believers should behave within the Corinthian congregation. What is valid for the one is valid for the other (Gal 1.13; 1 Cor 15.9; cf. 1 Cor 10.32; 11.22; Phil 3.6). Also Bultmann's gut feeling that the adscriptiones of both 1 Cor 1.2 and 2 Cor 1.2 actually meant 'to the church of God in so far as she is situated in Corinth', may not be far off the mark. ${ }^{106}$ At any rate, we can safely reckon with at least three instances (Gal 1.13 ; 1 Cor 12.28 ; 15.9 ) where Paul, in keeping with early Christian custom, used $\dot{\varepsilon} \kappa \kappa \lambda \eta \sigma i \alpha$ in an inclusive sense.

In Paul it is even more apparent that Jesus Christ was the factor which transformed this new $\dot{\varepsilon} \kappa \kappa \lambda \eta \sigma i \alpha$ from a primarily Jewish off-shoot into a Christian one. This is indicated by the qualification of $\varepsilon \kappa \kappa \lambda \eta \sigma i \alpha$ as being 'in Christ (Jesus)' (1 Thess 2.14; Gal 1.22), 'in the Lord Jesus Christ' (1 Thess 1.1) or simply 'the

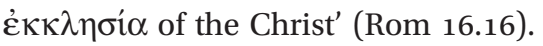

\subsubsection{Resumé}

Since our enquiry focuses on the roots of $\dot{\varepsilon} \kappa \kappa \lambda \eta \sigma i \alpha$ in Paul and not on his theology of $\dot{\varepsilon} \kappa \kappa \lambda \eta \sigma i \alpha$, a few concluding remarks must suffice:

1 In keeping with the historical development of the early Christian $\dot{\varepsilon} \kappa \kappa \lambda \eta \sigma i \alpha$ concept, its holistic character formed the initial focus. However, Paul's concern for the young churches within the orbit of his responsibility necessitated a focus on individual congregations. He was conscious of the universal church and, within the broad scope of his missionary vision, it was indeed important to him. But at this stage it was not yet an object of focused theological contemplation. In Ephesians and Colossians, as later in the Didache, ${ }^{107} \mathrm{a}$ more articulate view of the ecumenical church came into focus.

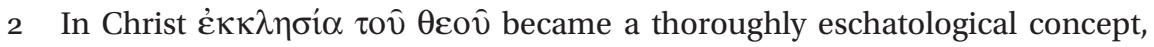
closely associated with, but still to be differentiated from 'kingdom of God'.

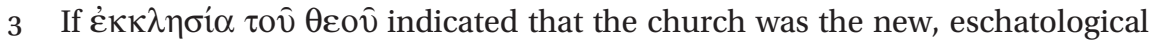
people of God, how did Paul envisage the relation between this new

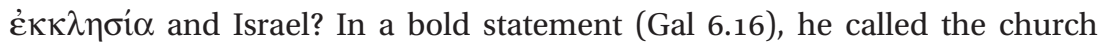

Gal 1.13 was a technical term for the mother church. However, Paul's specification that the congregations in Judea (1.22-23) were in fact the object of his persecution, makes this problematic.

106 Bultmann, Theologie, 96; also F. Hahn, 'Die Einheit der Kirche nach dem Zeugnis des Apostels Paulus', Ekklesiologie des Neuen Testaments: Für Karl Kertelge (ed. R. Kampling and T. Söding; Freiburg/Basel/Wien: Herder, 1996) 288-300 (288), and Dunn, Theology, 540. 107 Cf. the moving eucharistic prayers in Did. 9.4; 10.5. 
'the Israel of God'. This re-definition of Israel ${ }^{108}$ may either imply that the church replaced the historical Israel or that 'Israel' now included Israelite as

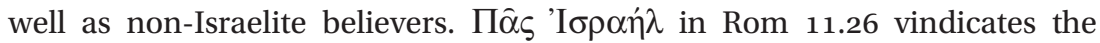
latter option. The future coming together of $\pi \hat{\alpha} \varsigma$ 'I $\sigma \rho \alpha \eta \dot{\lambda}$ will signal the final stage of a long trajectory originating in the desert traditions of Israel. This emphasizes salvation-historical continuity, not discontinuity.

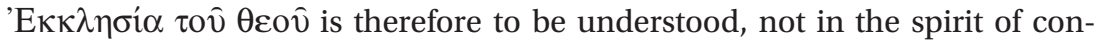
frontation, but as an open invitation to join in as God's salvation-historical drama draws towards its close.

4 Once again we have to reckon with a synergism of OT-Jewish and Hellenistic

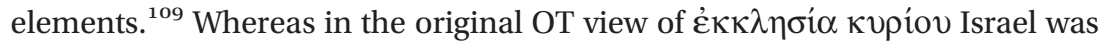
holistically seen as a holy people belonging to God, the Greek convention of using $\dot{\varepsilon} \kappa \kappa \lambda \eta \sigma i \alpha$ to indicate the assembly of the local $\delta \eta \mu \mathrm{\jmath}$ triggered and promoted the application of $\dot{\kappa} \kappa \kappa \lambda \eta \sigma i \alpha$ to local assemblies, as reflected particularly in the letters of Paul. Theologically, the OT heritage of Israel as the 'assembly of God' redefined christologically, indicates that the church, in its supra-local as well as its local sense, is the repristinated kernel of God's people, praying and working for the consummation of 'all Israel'.

\section{Major Conclusion}

By the time the NT documents were written, more than three and a half centuries of inter-group contact between Hellenistic and other cultures had passed. From around the middle of the first century BCE, Roman presence also made itself felt. For too long our research paid scant attention to the impact of interculturality. After the work of Martin Hengel and others, we should have known better. For too long we thought in terms of an either/or dichotomy and were hampered by ideological predispositions and tunnel vision. Our new approach should rather be one that focuses beyond the cultural divide. But this 'beyond' should not, in turn, become a new shibboleth. It should signify an unbiased openness to the possibility of interculturality. We may often find that various cultures interacted, as in the case of $\chi \alpha \dot{\rho} 1 \varsigma$ and $\dot{\varepsilon} \kappa \kappa \lambda \eta \sigma i \alpha$. In other instances it may turn out that a certain motif had either a Jewish or a Hellenistic or even a different (e.g. Roman) provenance. Also, infatuation with diverse cultural roots should not blind our eyes to the creative energy set free within an emerging faith movement such as early Christianity. And finally, the both-and does not mean that, theologically, Jewish and other influences balance one another. The Israelite basis of the Christian message remains its

108 Wolter, 'Entmachtung', 158, aptly describes it as a 'semantische Neubestimmung des IsraelBegriffs'.

109 Thus in particular Hahn, 'Einheit', 289, and Theologie, 1.275, 2.480-1. 
inalienable fountain-head. The waters flowing from that source certainly intermingled with other streams but did not forfeit their essential character. Certain elements in the Jewish-Christian religious tradition proved irreconcilable with Hellenism. In this more narrowly defined sense the 'battlefield' metaphor does contain an important truth. It will be necessary to distinguish between such hard-core biblical convictions and values, and the cultural vehicles by means of which they were communicated.

The study of origins may certainly help us to understand the genesis and development of NT notions. It may also provide us with important clues as to their semantics. But we should be cautious. Genetics are not decisive. Decisive is the way in which the early Christians adopted, adapted and contextualized these notions into their own religious universe. Only a conscientious synchronic study of individual NT texts will reveal how various cultural and religious phenomena were received and transformed in moving through the christological prism.

An exercise along these lines will certainly be full of pitfalls. One should, for instance, ask how thoroughly certain ideas or formulations were adopted - for instance, in the case of borrowed metaphors. Nevertheless, the 'beyond' position may deliver us from many former cul-de-sacs. It also holds promise for the future. As such, it may indeed signify the closing of one chapter and the beginning of a fascinating new one. ${ }^{110}$

110 Additional note: This may eventually result in a new Kittel.

\section{CAMBridge JDURNALS}

